\title{
Artelogie
}

Recherche sur les arts, le patrimoine et la littérature de l'Amérique latine

$12 \mid 2018$

Idiosyncrasie de l'indigénisme en Amérique latine.

Pluralité des sources et des appropriations extra-

latino-américaines

\section{El noroeste argentino como entrada al mundo andino: nativismo y americanismo en los debates estéticos de principios del siglo XX}

Pablo Fasce

\section{OpenEdition}

\section{Journals}

Edición electrónica

URL: http://journals.openedition.org/artelogie/1843

DOI: 10.4000/artelogie. 1843

ISSN: 2115-6395

Editor

Association ESCAL

Referencia electrónica

Pablo Fasce, «El noroeste argentino como entrada al mundo andino: nativismo y americanismo en los debates estéticos de principios del siglo XX », Artelogie [En línea], 12 | 2018, Publicado el 07 septiembre 2018, consultado el 30 abril 2019. URL : http://journals.openedition.org/artelogie/1843 DOI : 10.4000/artelogie. 1843

Este documento fue generado automáticamente el 30 abril 2019.

Association ESCAL 


\title{
El noroeste argentino como entrada al mundo andino: nativismo y americanismo en los debates estéticos de principios del siglo XX
}

\author{
Pablo Fasce
}

\section{Introducción}

1 Desde hace unos años la historiografía del arte argentino ha comenzado a afrontar una ardua tarea de revisión de las categorías y preconceptos heredados desde los inicios de la disciplina, en función de construir narrativas más amplias que permitan dar cuenta de la complejidad y diversidad de manifestaciones estéticas producidas a lo largo del país. Dentro de este conjunto de enfoques problemáticos, las indagaciones centradas en el siglo XX han tenido que lidiar con una antinomia que planteaba la oposición irresoluble entre un arte "nuevo" o "moderno", vinculado principalmente a las experiencias y lenguajes formales de las vanguardias europeas, y otro ligado a la "tradición" y de carácter "atrasado", que giró en torno a la representación de los paisajes y los tipos humanos "autóctonos" de las distintas regiones del territorio nacional. Las investigaciones recientes relativizaron aquella polaridad y señalaron que las obras artísticas vinculadas a lo nativo formaron parte de programas más amplios de modernización de la cultura local. Dentro de ese vasto campo de problemas, me interesa definir y describir los matices de uno de los núcleos temáticos más importantes de la época: los imaginarios estéticos sobre el noroeste argentino ${ }^{1}$.

2 Los trabajos que abordaron este universo de manifestaciones plásticas han utilizado distintos términos para nombrarlas y diferenciar sus variantes. Uno de los conceptos que se propusieron fue el de "nativismo"; esta noción ha sido utilizada para referirse a un conjunto de obras de amplia presencia en las disciplinas más importantes el Salón Nacional, centrada en la representación del paisaje y los tipos regionales o indígenas 
(PENHOS, 1999). También se ha utilizado el término "criollismo" para referirse a un conjunto de imágenes de diversa procedencia y circulación, todas ellas vinculadas a la caracterización del gaucho como tipo regional y étnico (ADAMOVSKY, 2016). Otros trabajos han optado por una diferenciación más específica. En el libro Cuzco-Buenos Aires los autores propusieron los conceptos de "hispanismo", "indigenismo" e "incaísmo" (a veces suplantado por el más específico "cuzqueñismo") para referirse a distintas modalidades de apropiación y representación de temas nativos en Argentina y Perú, donde cada uno de los nombres da cuenta del elemento sobre el que esa modalidad específica hace énfasis (AAVV, 2008). Roberto Amigo ha retomado estas categorías y ha planteado una diferenciación entre las ideas de indianismo (que supone una reconstrucción romántica e idealizada del pasado indígena) y el indigenismo (que trae hacia el presente el problema del indio y lo vincula con su condición de desposesión de la tierra) (AMIGO, 2014). En este caso, optaré por utilizar un solo concepto para referirme a todas las parcialidades: la noción de nativismo. Esta decisión puede ser problemática y se me podría objetar la falta de una mayor variedad de categorías (nativas o analíticas) para producir una lectura más precisa del fenómeno ${ }^{2}$. Sin embargo, sostengo que existe una ventaja al abarcar con un único término a ese amplio conjunto de imágenes. Es cierto que el nativismo incluyó obras muy diversas y que incluso existieron tensiones en su interior, pero sus diferencias no fueron producto de programas ideológicos o normativos sino de elecciones de los agentes involucrados, que construyeron fronteras fluidas y circunstanciales en su práctica. En numerosas ocasiones encontramos en los discursos críticos de la época una valorización similar del paisaje andino, el pampeano o de la serranía cordobesa, así como artistas que pintaron de modo casi indistinto al indígena del altiplano, el gaucho del litoral o incluso a los campesinos españoles. En ese sentido, la amplitud del concepto de nativismo resulta operativa, puesto que permite dar cuenta de que el fenómeno se trató de un campo temático en constante definición.

3 Aun así, en este marco general existieron ocasiones en las que las representaciones del noroeste argentino se destacaron entre el conjunto de las variantes del repertorio nativista. Al observar las producciones del período no solo nos encontramos con una amplia proporción dedicada a la región de nuestro estudio, sino también con un gran número de variaciones sobre el tema que, en sus múltiples encarnaciones, disputaron el centro de la escena ${ }^{3}$. La perspectiva que propongo para explicar el particular interés que suscitó el noroeste se centra en el hecho de que en él se pueden hallar todos los aspectos centrales sobre los que giraron las definiciones del nativismo, característica que lo distinguió del resto de las regiones del país. El interés por lo "telúrico" quedaba satisfecho por la presencia de la cordillera de los Andes, que ofrecía paisajes de una potencia sublime a los que la serranía cordobesa, la llanura pampeana o los bosques patagónicos no podían igualar. Además, el noroeste también ofrecía las huellas de un pasado aún visible, que podía ser identificado tanto en la cultura material de los pueblos precolombinos (entre los que se contaba el imperio Inca) como en el patrimonio arquitectónico de la época colonial (que evidenciaba la integración de la región al antiguo Virreinato del Alto Perú); ese pasado también tenía un correlato con el presente de sus pobladores, entre los que se contaba un amplio número de mestizos y descendientes de indígenas que sirvieron de modelos para los pintores que, en el contexto de un enorme aluvión inmigratorio, se dirigieron a aquellas provincias en búsqueda del "criollo de tierra adentro". Al mismo tiempo, todas estas características hicieron del noroeste el territorio que permitió que el nativismo derivara hacia el americanismo, planteando un enlace entre el "alma nacional" argentina y la región sudamericana. 
4 En las páginas que siguen reconstruiré algunos de los principales aspectos de los imaginarios visuales y estéticos sobre el noroeste argentino gestados durante las primeras décadas del siglo XX. En primera instancia, indagaré en los vínculos que existieron entre estas manifestaciones artísticas y los debates intelectuales y políticos de la época. Posteriormente, estudiaré algunos de los primeros modelos visuales establecidos por algunos de los artistas que se recorrieron el noroeste y recopilaré algunas de las principales percepciones que ellos despertaron en la crítica de arte contemporánea. Finalmente, analizaré la penetración de los imaginarios sobre la región en el discurso historiográfico y la gestión de las instituciones oficiales del campo artístico. Como veremos a lo largo de este recorrido, el noroeste argentino fue un polo de atracción para artistas e intelectuales, a quienes les permitió pensar un enlace con una herencia cultural de dimensión americana.

\section{Un nuevo mapa de ideas para la definición del "arte nacional"}

Los rincones de la vieja colonia destacan en provincias la herencia práctica, efectiva, de un propósito de belleza que luego no supimos utilizar, sorprendiéndonos que contando con tantos elementos de comparación y de enseñanza en el estudio, caminemos de costado, como los cangrejos, sin saber mirar atrás...

(RIPAMONTE, 1926: 111)

Durante los años cercanos a la celebración del Centenario de la Revolución de Mayo tuvo lugar un proceso que marcó un antes y un después en la historia del arte argentino. Es ineludible referirse a la Exposición Internacional de Arte del Centenario de 1910: fue la primera muestra oficial organizada por el Estado (antecedió en un año a la primera edición del Salón Nacional de Bellas Artes) y presentó una de las primeras oportunidades de comparación directa entre las escuelas artísticas de las naciones "civilizadas" y el incipiente desarrollo estético del país (MUÑOZ, 1999). Pero además, esta muestra formó parte de un proceso de reconfiguración del mapa de las artes. Una generación de artistas jóvenes, la mayoría vinculados al grupo $\mathrm{Nexus}^{4}$, fue consagrada por la mirada de la crítica y desplazó a la camada anterior de los lugares que ocupaban en las instituciones artísticas 5, hechos que la historiografía del arte ha considerado como signos de una primera consolidación del campo artístico local (MUÑOZ, 1998). Si bien el enfrentamiento más evidente entre estas dos generaciones pareció tener su centro en la gestión de los organismos estatales ${ }^{6}$, el problema de la "escuela" argentina también fue un factor de división. En contraposición a la plástica de espíritu cosmopolita y alimentada por ideas positivistas ${ }^{7}$, los artistas de la generación de Nexus adoptaron un enfoque "espiritualista": con otras referencias en mente (tales como la pintura del regionalismo español ${ }^{8} \mathrm{y}$ algunos aspectos de la técnica impresionista) sus obras se avocaron a la representación del paisaje y los tipos regionales del país, temas centrales para definir un arte verdaderamente "argentino".

6 Para comprender el giro nativista es necesario indagar sus vínculos con las ideas en circulación durante la época. El Centenario de Mayo también fue el momento de surgimiento de una camada de escritores que sentó las bases de una nueva tradición intelectual. Además de ser los primeros en dedicarse de modo profesional a la escritura, varios de ellos se habían criado en las provincias y provenían de antiguas elites sociales 
(ALTAMIRANO Y SARLO: 1997). Posiblemente este pasado común, en conjunción con la atención que suscitaba la masiva inmigración que recibía el país ${ }^{9}$, hayan sido los factores determinantes en su acercamiento al problema de la identidad nacional. Los intelectuales de la generación del Centenario iniciaron el camino del primer nacionalismo cultural: para ellos la solución al problema de la identidad argentina residía en la apelación a prácticas, valores y tradiciones del pasado para producir una nueva amalgama social. Esta posición ha sido interpretada como la reacción de una intelligentsia incipiente que, frente al "acoso" de las masas y la modernización, se escudó en la revalorización de la cultura de los sectores pobres nativos (GOEBEL, 2013: 57).

7 Los referentes más relevantes de esta tradición fueron Manuel Gálvez (1882-1962), Ricardo Rojas (1882-1957) y Leopoldo Lugones (1874-1938). Existen matices que distinguen a sus proyectos intelectuales entre sí: si Gálvez planteó la necesidad de superar el creciente materialismo en el que estaba sumida la Argentina a partir de la recuperación de una matriz originaria compuesta por el catolicismo y la tradición cultural española, Rojas se inclinó hacia un enfoque más inclusivo centrado la concordia del "crisol de razas" a partir del hermanamiento producido por el espíritu de la tierra, mientras que Lugones expresó un contundente rechazo a la religión católica y a la masa igualitaria de los inmigrantes y propuso una lectura del alma nacional que desdeñaba al mundo indígena y trazaba un camino que unía a gauchos y caudillos con el Cantar del mío Cid y los poemas homéricos (DEVOTO, 2002). Las distancias entre estos tres autores se incrementaron a lo largo de sus trayectorias ${ }^{10}$. Aun así, coincidieron en un punto central: sin oponerse al proyecto historiográfico y educativo del liberalismo, fueron capaces de superarlo en la creación de una tradición cultural que definiera la "argentinidad"11.

8 La operación que los intelectuales del Centenario de Mayo hicieron sobre la literatura es conocida. Rojas y Lugones tuvieron un rol central en la elevación del Martín Fierro al pedestal más elevado del canon nacional: mientras el primero veía en su protagonista a un héroe cívico en cuya voz se fusionaban el romance caballeresco y la vida indiana de América, el otro sostenía que el texto debía ser considerado como el primer poema nacional del género épico ${ }^{12}$. La existencia de un género literario que se apropiaba de la voz del gaucho permitió que estos pensadores erigieran a las clases populares del mundo rural pampeano como el sujeto social más representativo del "espíritu nacional"13. No obstante, las artes plásticas plantearon otra situación. Si bien la llanura pampeana formó parte de los temas del paisaje nacional desde el siglo XIX, su asociación a la temática sarmientina del "desierto" le quitó protagonismo cuando la conflictividad social se trasladó a la ciudad receptora de la inmigración (MALOSETTI COSTA Y PENHOS, 1991); además, la simplicidad y homogeneidad de su relieve y vegetación era un problema para las artes visuales, tal como lo había señalado Eduardo Schiaffino en su polémica de 1894 con Rafael Obligado alrededor del paisaje nacional (MALOSETTI COSTA, 2001). Como veremos más adelante, posiblemente estas razones determinaron que cuando los intelectuales del Centenario expresaron sus preferencias en materia de artes plásticas, en casi todas las oportunidades su mirada se dirigió hacia las obras que representaban temas del noroeste argentino.

9 También es necesario señalar el vínculo que existió entre el interés por el pasado prehispánico de algunos de los intelectuales del Centenario y el desarrollo de la arqueología en el contexto de los debates americanistas. A lo largo de las tres últimas décadas del siglo XIX los trabajos de Florentino Ameghino, Samuel Lafone Quevedo, Juan Bautista Ambrosetti y Adán Quiroga, entre otros, se concentraron en el análisis de los 
restos materiales de las culturas que habitaron la región; contrastando la información de las excavaciones con los registros etnográficos, el folklore y las fuentes históricas, estos investigadores confluyeron en la idea de que había existido una "civilización calchaquí" previa al período de ocupación inca, que alcanzó los mayores desarrollos en metalurgia y alfarería pero había decaído para la llegada del español ${ }^{14}$. De este modo, los científicos argentinos se incorporaron a los debates americanistas que acontecían en Europa mientras le daban forma a las colecciones de los museos locales en los que las colecciones calchaquíes tuvieron un lugar central ${ }^{15}$, como fue el caso del Museo Etnográfico de la Universidad de Buenos Aires durante las gestiones de Ambrosetti y Salvador Debenedetti, que privilegiaron la investigación de las culturas arqueológicas del noroeste por encima de otras regiones del país ${ }^{16}$. La dimensión visual de los objetos precolombinos cautivó el interés de algunos arqueólogos: Lafone Quevedo, Quiroga y Ambrosetti en varios de sus trabajos afirmaron que en las piezas calchaquíes podía encontrarse elementos de un lenguaje jeroglífico junto con iconografías con significados simbólicos precisos (BOVISIO, 2014). Los viajes de arqueólogos y artistas se enlazaron en más de una ocasión y se imbricaron en el descubrimiento de una tradición visual prehispánica a utilizar en aquel presente.

El recambio generacional en el ámbito de las artes plásticas produjo un giro en la pregunta sobre la naturaleza del "arte nacional", que se alimentó de la perspectiva espiritualista de los intelectuales y de la cultura material puesta a disposición por los arqueólogos. En el noroeste se conjugaban distintos elementos atractivos para esta nueva búsqueda: un paisaje complejo en términos visuales, un conjunto de tipos humanos alrededor de los que se podía reconfigurar la definición del "nativo" o el "criollo" y un pasado disponible estratificado en múltiples capas. En ese contexto, no pasaría mucho tiempo hasta que los pintores y escultores fueran al encuentro de la región.

\section{Itinerarios, lecturas e imágenes del mundo andino}

11 En su libro La inmortalidad de una patria (1942), Atilio Chiáppori (1880-1947), crítico y (en ese entonces) ex director del Museo Nacional de Bellas Artes (en adelante MNBA), recordaba la situación a la que se habían enfrentado los artistas interesados por responder a la pregunta del arte nacional a partir de la segunda década del siglo XX:

Así les ocurrió a nuestros jóvenes pintores, en 1914, al repatriarlos sorpresivamente la guerra europea con las retinas todavía impregnadas de «il bel paese» de «le doux pays» o del dramático «retablo español»... Encontraron sucio el río, chata la ciudad; municipal la campiña; ázima y monótona la Pampa (...) Comenzó entonces, la carrera al Norte: Tucumán, La Rioja, Salta, Jujuy; ¡más arriba, aún, el Altiplano!... Y casi todos volvieron, después de tres o seis meses, con talentosos estudios de tipos indígenas, de escenas regionales -mercados, bailes, procesiones-, pero con muy escasos o ningún paisaje... Les resultó hermético dentro de su impotencia esquemática (...) Y la lección era convivir -no tres o seis meses o un año, sino hasta la identificación- con la montaña, para arrebatarle, en un acto místico, no solo su secreto cromático, sino principalmente su secreto cósmico. (CHIÁPPORI, 1942: 29-30)

12 La cita esconde varias claves de la atracción que generó el noroeste. El estallido de la guerra significó el fin de una primera etapa en la historia de las becas de formación europea, que se habían consolidado tras la formación de la Comisión Nacional de Bellas Artes (en adelante, CNBA) en 1897. No tenemos certeza de si este conflicto llevó en ese 
momento a la creación de programas de viajes formativos en el nuevo continente, pero lo cierto es que, con o sin apoyo de las instituciones oficiales, un número creciente de artistas comenzó a desplazarse hacia las provincias en busca de aquellos motivos en los que la crítica veía a la escuela nacional. Una de las opciones más frecuentes que coexistió a la del noroeste había sido el paisaje serrano de Córdoba, cuyo paisaje concentró alrededor de la mitad del volumen de obras nativistas en el Salón Nacional hasta la mitad del siglo (PENHOS, 1999: 124). Sin embargo, aquella región no disponía de un conjunto de tipos humanos a los que los artistas pudieran convertir en arquetipos del nativo "incontaminado"; en cambio, el norte era la única zona del país en la que se combinaban todos los factores. Además, la enorme extensión y altitud de los Andes los aproximaba a la idea de lo sublime: quizás por esto Chiáppori destacó la dificultad inherente en representarlos y afirmó la necesidad de alcanzar una "identificación" con la montaña que no era posible desde la perspectiva del turista.

13 Ya en los primeros años de la década de 1910 varios artistas argentinos se desplazaron hacia el noroeste para comenzar a construir los modelos visuales sobre la representación de temas norteños; la crítica se mostró particularmente receptiva a estos ensayos. Pompeyo Boggio (1880-1938) fue el primero en cosechar el éxito tras el encuentro con la región: tras ser invitado por los arqueólogos Ambrosetti y Salvador Debenedetti, en 1911 arribó a Tilcara junto al pintor José Antonio Terry ${ }^{17}$ y al año siguiente en el Salón Nacional recibió el premio adquisición en pintura (la máxima distinción que podía obtenerse en ese momento) por su obra titulada Tipos quichuas de la Quebrada de Humahuaca (Figura 1). La obra de Boggio está dominada por las dos figuras en primer plano que ocupan aproximadamente dos terceras partes de la superficie pictórica: se trata de un hombre y una mujer, posiblemente un matrimonio, vestidos con ponchos norteños (el rojo es el elemento cromático más llamativo de la tela) que llevan dos grandes vasijas de barro cocido (él en sus manos, ella sobre su cabeza). El rostro de barba y piel oscura del varón indica que probablemente sea un mestizo. En un plano posterior, alineada con sus cabezas se recorta la fachada blanca de la iglesia de Nuestra Señora del Rosario de Tilcara, cuyo aspecto es inmediatamente asociable a los muchos ejemplos de arquitectura colonial de la Quebrada. Entre el edificio y la pareja se puede ver a un grupo de mujeres que podrían ser parte de una feria; la escena está enmarcada hacia el fondo por un cerco de montañas. Como indica el título, la pintura pretende constituirse como un muestrario de los pobladores del norte y sus costumbres tradicionales, expuestos a modo de arquetipos de una región sin tiempo. Gálvez, que por esos años oficiaba como crítico de la revista Nosotros, fue severo con la obra de Boggio pero también vio en ella lo que podría ser el comienzo una "escuela" de arte argentino:

El cuadro premiado «Tipos quichuas de la Quebrada de Humahuaca» es una de las obras más simpáticas de la exposición (...) El autor no demuestra poseer un gran sentido de la realidad. Pero, y he aquí su mérito positivo, ha sabido buscar el carácter. Lo tienen sus tipos, su paisaje, la iglesia del fondo. No me detendré más sobre esta tela que no es una realidad de arte sino más bien una promesa, pero quiero elogiar una vez más al autor por haber ido a pintar a Jujuy. Aquellas comarcas son lo más bello que posee nuestro país. Tiene no sé qué de místico y de fatalista (...) Tales tierras tienen algo de común con las castellanas y concretan toda el alma de una raza; jaquella raza quichua, misteriosa y vencida, que puebla el silencio de las punas con los ayes de sus quenas dolientes! (GALVEZ, 1916: 48 y 49)

14 Las distintas variantes en los modos de representar los temas norteños fueron una oportunidad para que los intelectuales pusieran en juego las diferencias de sus enfoques. En un artículo publicado en La Nación, Lugones intentó replicar su operación sobre el 
texto de Hernández al afirmar que “(...) dentro de pocos años la pintura de Alfredo Gramajo Gutiérrez será al país lo que es la poesía de Martín Fierro: una realización definitiva, un monumento fundamental." (LUGONES, 1920). Para el poeta “(...) el artista nacional es aquel que sabe vivir la humanidad en la patria", condición que encontraba en el modo de abordar el drama humano de las clases populares norteñas que caracterizaba a su pintura. Gramajo Gutiérrez (1893-1961) nació en Tucumán pero tuvo que radicarse con su familia en Buenos Aires por la muerte de su padre; a los catorce años comenzó a trabajar en la Administración General de los Ferrocarriles del Estado, lo que le permitió retornar al noroeste en varias ocasiones. Posiblemente el interés de Lugones por sus pinturas estuvo motivado por la recuperación de la cultura popular que el artista realizaba en ellas. Retablo de Jesús (Figura 2), que representa las imágenes de bulto y los ritos católicos de Semana Santa, se compone de tres paneles realizados en distintos viajes a Catamarca ${ }^{18}$ y que en conjunto forman una suerte de pequeño retablo, similar a los de factura popular que pueden encontrarse en capillas y casas familiares del norte. Gramajo Gutiérrez también abordó los mitos y leyendas con raíces en el mundo precolombino. En 1946 ilustró una reedición de El país de la selva, libro en el que Ricardo Rojas recopiló historias y leyendas del noroeste; en la imagen que refiere a la historia de la salamanca (Figura 3) el pintor sitúa en el monte santiagueño a un gaucho que desde el borde de la cueva espía el aquelarre que se desarrolla en su interior, en el que el supay y los animales telúricos enseñan música y brujería al enjambre sinuoso de sus concurrentes.

15 Posiblemente el pintor de temas norteños más exitoso fue Jorge Bermúdez (1883-1926), que a pesar de la brevedad de su carrera recibió un amplio número de premios y la aprobación casi unánime de la crítica. Tras iniciar su formación en la Academia Nacional de Bellas Artes, en 1909 Bermúdez recibió una beca que le permitió continuar su formación en Europa; tras dos años de estudios en la Academie Julien de París, ingresó al taller del pintor vasco Ignacio Zuloaga, que lo introdujo en el universo pictórico del regionalismo español. Durante ese período también conservó una presencia en la escena artística porteña, tal como lo demuestra su envío de la obra Castilla la Vieja al Salón Nacional de 1912; en el mismo artículo en el que apreció la obra de Boggio, Gálvez defendió la calidad de la pintura de Bermúdez frente a las voces que la acusaban de ser una copia del estilo del maestro español ${ }^{19}$ :

Si Jorge Bermúdez imita a Zuloaga, debemos perdonárselo en gracia a la maravilla del modelo, a la meritoria ejecución del cuadro, y, sobre todo, a la excelencia espiritual que revela su inclinación zuloaguesca, ya que para imitar bien a un autor es preciso tener con él una decisiva semejanza de espíritu, dicho sea esto en elogio de Bermúdez. Por lo demás, otros autores a quienes se alaba mucho, han imitado también a Zuloaga (...) Y sobre todo, que pictóricamente el cuadro de Bermúdez no merece ningún tipo de desprecio. Algunos de sus tipos, presentados aisladamente, habrían llamado la atención. No son superiores a los suyos los del premiado señor Boggio. (GÁLVEZ, 1916: 40)

16 Muy poco tiempo después de este episodio la obra de Bermúdez obtuvo reconocimientos que dejaron atrás la comparación. En 1913 retornó al país y tuvo su primera exposición individual en el salón Philipon; pocos meses después durante ese mismo año obtuvo el premio adquisición de pintura en el Salón Nacional por El poncho rojo, obra realizada en una estancia de la provincia de Buenos Aires y que nuevamente recibió los elogios de Gálvez, que la consideró como la evidencia de la consumación de un estilo personal y maduro $^{20}$. En 1914 Bermúdez emprendió su primer viaje hacia el noroeste, aparentemente gracias al consejo de Zuloaga, quien consideraba que en el "interior" del país podría 
encontrar el tema de una gran obra nacional análoga a la que él había realizado en Segovia ${ }^{21}$; si bien no se conoce con certeza su itinerario, sabemos que se asentó temporalmente en Jujuy y Catamarca ${ }^{22}$. En julio de ese año expuso los resultados del recorrido en una muestra realizada en las salas de la CNBA, en la que el MNBA adquirió Gallero viejo (Figura 4): la pintura tiene como figura principal a un anciano nativo que mira hacia fuera de cuadro y enseña uno de sus animales; la imagen condensa el retrato de tipos con la escena de feria y la riña de gallos. Fuera del rostro del gallero, las formas pierden detalle hasta casi volverse manchas cromáticas que vibran buscando emular el efecto de la luz del altiplano; los ojos alineados con el cordón montañoso articulan a la figura con el paisaje, planteando una metáfora acerca de la "comunión" entre el hombre originario y su entorno. A lo largo de los diez años siguientes ${ }^{23}$ Bermúdez continuó viajando por el noroeste y cosechó numerosas distinciones, tales como los primeros premios del Salón de Córdoba (en 1916) y el Salón de Otoño Rosario (en 1917), la medalla de oro en pintura de la Exposición Universal de San Francisco de 1922; también fue designado en cargos dentro de instituciones oficiales como la Academia Nacional (donde ofició como profesor de pintura desde 1915) y la CNBA (en la que ingresó como vocal de la comisión directiva en 1920). Ricardo Rojas incluyó al pintor junto a Fernando Fader y Cesáreo Bernaldo de Quirós en el "núcleo glorioso de la escuela 'euríndica"' (ROJAS, 1924: 52); ya anteriormente le había dedicado un ensayo breve que se publicó en el catálogo de una exposición individual de Bermúdez realizada en la galería Witcomb, donde afirmó con contundencia que el pintor ya había logrado constituirse como uno de los valores más relevantes de un arte verdaderamente nacional:

\begin{abstract}
Es hora feliz para un pueblo, aquella en que se puede señalar un artista cuyo temperamento equilibra sus varias influencias tradicionales renovándolas para una función de trascendencia histórica, como ocurre en el caso de Jorge Bermúdez. Argentino como es, creó una pintura profundamente argentina; pero como lo argentino es producto de lo indígena y de lo español, o más ampliamente de lo americano y de lo europeo, Bermúdez funde la heterogénea realidad en su crisol personalísimo, dándonos una visión de la patria purificada en símbolos de belleza.

(ROJAS, 1923)
\end{abstract}

17 Como hemos señalado hasta aquí, los pintores y escultores que recorrieron la región descubrieron una variedad de elementos sobre los que enfocaron su mirada: el paisaje montañoso, los tipos humanos, la arquitectura colonial, la religiosidad y las costumbres y ritos populares fueron componentes principales de las imágenes construidas. La presencia o ausencia de estos aspectos en cada obra da cuenta del proceso activo de selección por parte de los artistas a la hora de elaborar las representaciones sobre el noroeste; las combinaciones y el énfasis puesto en cada parte también implicaron distintas conceptualizaciones sobre la identidad de la región. Este proceso estuvo acompañado por las voces de los intelectuales, que a través del ejercicio de la crítica aportaron a la construcción imaginaria del noroeste como el espacio privilegiado del nuevo "arte nacional".

\title{
El noroeste y las instituciones: la oficialización de la mirada hacia América
}

18 Durante aquellos años también tuvo lugar un proceso de reformulación del mapa institucional del campo artístico. La nueva CNBA organizada en 1924 y la Academia Nacional de Bellas Artes (en adelante, ANBA) ${ }^{24}$ creada en 1936 fueron concebidas como 
organismos centralizados que orientarían el desarrollo de la actividad en el país. Pero además, estas instituciones contribuyeron a la consolidación de la mirada y el pensamiento estético que tuvo como eje a la América "profunda" (y al noroeste como la vía nacional hacia ella).

El arquitecto e historiador Martín Noel fue una figura central de este proceso, ya que ocupó la presidencia de la CNBA desde 1920 hasta 1930 y luego dirigió la ANBA entre 1938 hasta su muerte en 1964, oficiando como vicepresidente hasta 1944 y luego como presidente (salvo por el período entre 1952 y 1955 en el que el organismo estuvo cerrado); sus gestiones estuvieron regidas por la intención de propiciar el desarrollo cultural de manera integral exaltando sus tradiciones, lo que él mismo consideraba como una tarea patriótica (BERJMAN Y WECHSLER, 1995). Junto con Ángel Guido y Héctor Greslebin, formó parte de una generación de arquitectos que se opuso a la hegemonía del eclecticismo (representada por su maestro Alejandro Christophersen) a partir de la revalorización del estilo colonial: mientras que sus antecesores consideraban que las edificaciones americanas no eran más que una copia popular y degradada de modelos españoles, estos jóvenes constructores vieron en ellas las primeras producciones locales de una estética nativa (GUTMAN, 1995). En ese sentido, el discurso de Noel en la apertura de la sección de arte del II ${ }^{\circ}$ Congreso de Historia de América realizado en 1937 en Buenos Aires puede ser entendido como una toma de posición y un programa a desarrollar:

El americanismo ha sido más bien en lo plástico hasta hace poco una mera curiosidad de los arqueólogos, que tan sólo han contemplado bajo el prisma de los laboratorios encargados de adquirir conocimientos para la ciencia y esto en el campo exclusivo de lo precolombino.

Se ha descuidado, por consiguiente, la valorización del contenido estético traído por la conquista y la acción colonial a los centros medulares del nuevo mundo. Expansión renacentista que enraíza en su suelo y que concluye por determinar nada menos que la afirmación de su voluntad autóctona en el concierto de las formas universales (...)

América con el arduo interrogante de sus culturas desvanecidas en la quimera de las leyendas y en la fisionomía vacilante de sus ruinas, pero grávida en el contenido estético de su arquitectura y de su plástica.

Y España que cumpliendo con su destino conforme al pensamiento del mundo occidental fue el brazo y oriflama que conquista y evangeliza un nuevo continente. De suerte que, como parte de él, su arcaísmo tectónico se integra a la historia de las artes. (NOEL. 1945: 38)

A través de estas palabras, Noel dejó en evidencia que se proponía ampliar el campo del americanismo a través de una operación de dos caras: por un lado pretendía introducir a la historia del arte en la arena de los debates sobre la historia y la realidad del nuevo continente, por otra parte esperaba incorporar a la arquitectura colonial como objeto de estudio a partir de la legitimación de su condición estética ${ }^{25}$. Consecuente con su adhesión al pensamiento de Rojas, consideraba que en el encuentro del mundo indígena y la cultura española se había producido la génesis de un nuevo estilo arquitectónico, en el que se combinaban la "proporción desantropomórfica precolombina" (es decir, que excede la dimensiones humanas) con el pensamiento estético humanista europeo (NOEL, 1945: 152). Noel y Ángel Guido fueron los máximos exponentes en Argentina de un movimiento que, desde la teoría y la práctica de la arquitectura, intentó posicionar el concepto de la "fusión hispano-indígena" como eje de los problemas del americanismo; así ambos produjeron las primeras contribuciones desde la historia del arte que revalorizaron el 
pasado indígena y colonial, vinculando desde esa especificidad disciplinar al noroeste con los Andes Centrales ${ }^{26}$.

La designación de Noel al frente de la CNBA en 1920 también implicó la renovación de sus miembros, que incluyeron a las máximas autoridades de la academia y el $\mathrm{MNBA}^{27}$; la mayor parte de los nombres permanecieron tras la formación de la ANBA, lo que da cuenta de la hegemonía que esta generación de agentes culturales supo mantener mientras estuvo en actividad. En el terreno de las artes plásticas, esta gestión encaró una serie de iniciativas tales como la adecuación de la futura sede del MNBA (inaugurada en 1933 durante la dirección de Chiáppori), el incremento de los premios del Salón Nacional y la presentación de un plan integral de reforma de la educación artística, que implicaba la separación de la Academia en tres instituciones independientes: la Escuela Nacional Preparatoria de Dibujo (dirigida por Carlos Ripamonte), la Escuela Nacional de Artes Decorativas (bajo la responsabilidad de Collivadino) y la Escuela Superior de Bellas Artes (a cargo de Cárcova). En la memoria presentada al ministro de instrucción pública Ernesto Padilla, los artículos 21 y 27 de los planes de estudio aprobados en 1921 describían el concurso para el "premio América", vigente para las tres secciones de la Escuela Superior y que retribuía a los ganadores con una beca de un año de duración para viajar por el país o el continente; aunque desconocemos los nombres de los beneficiados ${ }^{28}$ podemos afirmar que esta nueva modalidad posibilitaba (al menos desde su concepción) profundizar la vía de indagación que habían inaugurado los artistas que realizaron los primeros viajes hacia el noroeste en la década anterior.

Pero la acción más relevante que Noel realizó desde las instituciones oficiales para consolidar su mirada sobre el pasado colonial fue la creación de la serie Documentos de Arte Argentino, que la ANBA comenzó a publicar en 1939. Estos libros se presentaban como un registro del patrimonio artístico de distintas regiones del país, plasmado a través de un ensayo a cargo de un especialista (seleccionado por Noel en cada ocasión) y un conjunto de instantáneas tomadas por el fotógrafo alemán Hans Mann; la amplia mayoría de los títulos estuvo dedicada al noroeste y las imágenes de Mann reprodujeron en un nuevo lenguaje buena parte de los códigos establecidos por los pintores que venían representando la región desde hacía varias décadas ${ }^{29}$ (Figura 5). Una segunda serie titulada Documentos de arte colonial sudamericano que comenzó a ser publicada en 1943 amplió el corpus para incluir las obras coloniales de Bolivia y Perú, lo que puede ser entendido como una reafirmación del vínculo entre el noroeste argentino y los Andes Centrales señalado por las investigaciones de Noel y Guido.

Más allá de las gestiones de Noel, otros organismos e instituciones del Estado replicaron las iniciativas que movilizaron a los artistas nacionales hacia la región andina. Uno de ellos fue la Comisión Nacional de Cultura, creada por el poder ejecutivo en 1933 e integrada por representantes de asociaciones de escritores, músicos y dramaturgos pero también por entidades del ámbito de las ciencias; la Comisión estuvo encargada de poner en acto las reglamentaciones establecidas por la ley 11.723, que contemplaba una variedad de premios a la producción artística y científica y un sistema de becas de perfeccionamiento dentro del país y en el exterior, pero que a partir de 1939 se circunscribió solo al territorio americano debido al estallido de la guerra (ROSSI, 2012). Gracias a esta iniciativa, un nuevo contingente de artistas argentinos recorrió el noroeste con el objetivo de realizar estudios del paisaje, la fauna y los tipos raciales de la región; a partir de 1941 también se sumó otra beca dispensada por el Ministerio de Justicia e Instrucción Pública para los estudiantes de la Escuela Superior de Bellas Artes. ${ }^{30}$ 
24 En suma, si las primeras representaciones del norte fueron realizadas por artistas movidos por intereses y redes personales, con la consolidación de las instituciones artísticas nacionales y el surgimiento de nuevos organismos, una nueva generación de gestores culturales (varios de ellos formados por las ideas de Rojas) alcanzó los puestos de mayor relevancia y transformó al interés por lo nativo en un asunto de Estado. Aunque el nuevo cierre de la frontera europea alimentó los viajes hacia la "América profunda", las rutas que se consolidaron ya llevaban varios años siendo recorridas.

\section{Conclusiones}

25 El sintético recorrido que realizamos a lo largo del artículo intentó recuperar las características principales de los imaginarios visuales sobre el noroeste argentino elaborados en el contexto del auge del nativismo en Argentina. Esta indagación no agota el tema y precisa ser ampliada en escrituras posteriores; es ineludible la necesidad de profundizar en el diálogo entre las voces que visitamos y otras provenientes de otras tradiciones estético-políticas que intervinieron en la definición de lo nativo, tales como las izquierdas, las vanguardias y el peronismo. No obstante, los resultados obtenidos hasta este punto nos permiten establecer algunas reflexiones.

El noroeste argentino fue un tema central durante algunos de los momentos de mayor vitalidad del nativismo: la diversidad de aspectos a partir de los cuales los artistas construyeron los imaginarios visuales da cuenta de la complejidad que la región ofrecía a la discusión estético-intelectual en comparación con otras zonas del país. Por otro lado, aunque este campo de debates artísticos tuvo un estrecho vínculo con una tradición intelectual nacionalista reactiva al proceso de modernización social que acontecía en el país a principios de siglo XX, el nativismo también tuvo derivas de carácter progresivo: esto quedó constatado fundamentalmente cuando esas ideas permearon las instituciones oficiales (a través de gestiones como la de Chiáppori y Noel) y las orientaron hacia el desarrollo de vías interiores de circulación de artistas y patrimonio. Finalmente, el interés por el noroeste permitió que el pensamiento estético argentino construyera una vía de comunicación entre la historia local y otra de carácter transnacional en la que los Andes se constituían como un escenario dinámico de intercambios y nexos culturales; aunque estos vínculos no dejan de ser construcciones historiográficas, nos permiten conocer itinerarios de la plástica argentina plausibles de ser conectados con los indigenismos latinoamericanos y que otras genealogías de la modernidad estética, centradas en la autonomía de la forma, tendieron a obturar. 


\section{Imágenes}

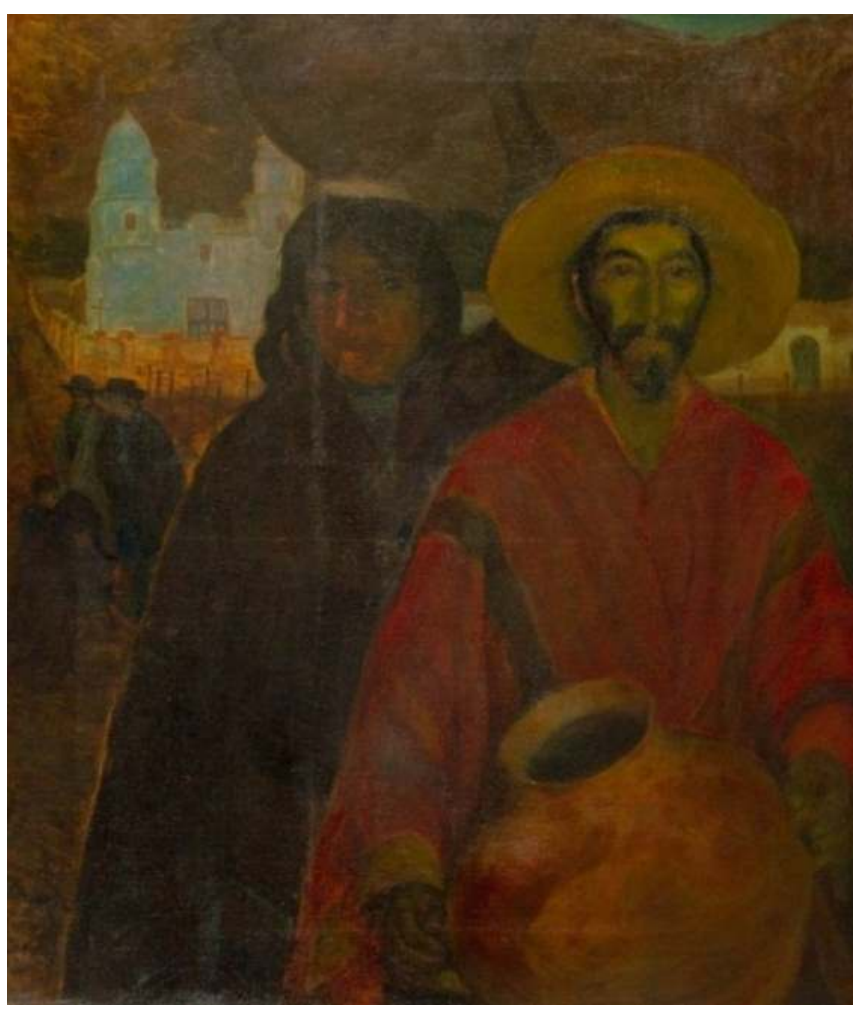

Figura 1: Pompeo Boggio, Tipos quichuas de la Quebrada de Humahuaca, 1912, óleo sobre tela, 105 x 90 cm. Colección Museo Nacional de Bellas Artes, Buenos Aires.

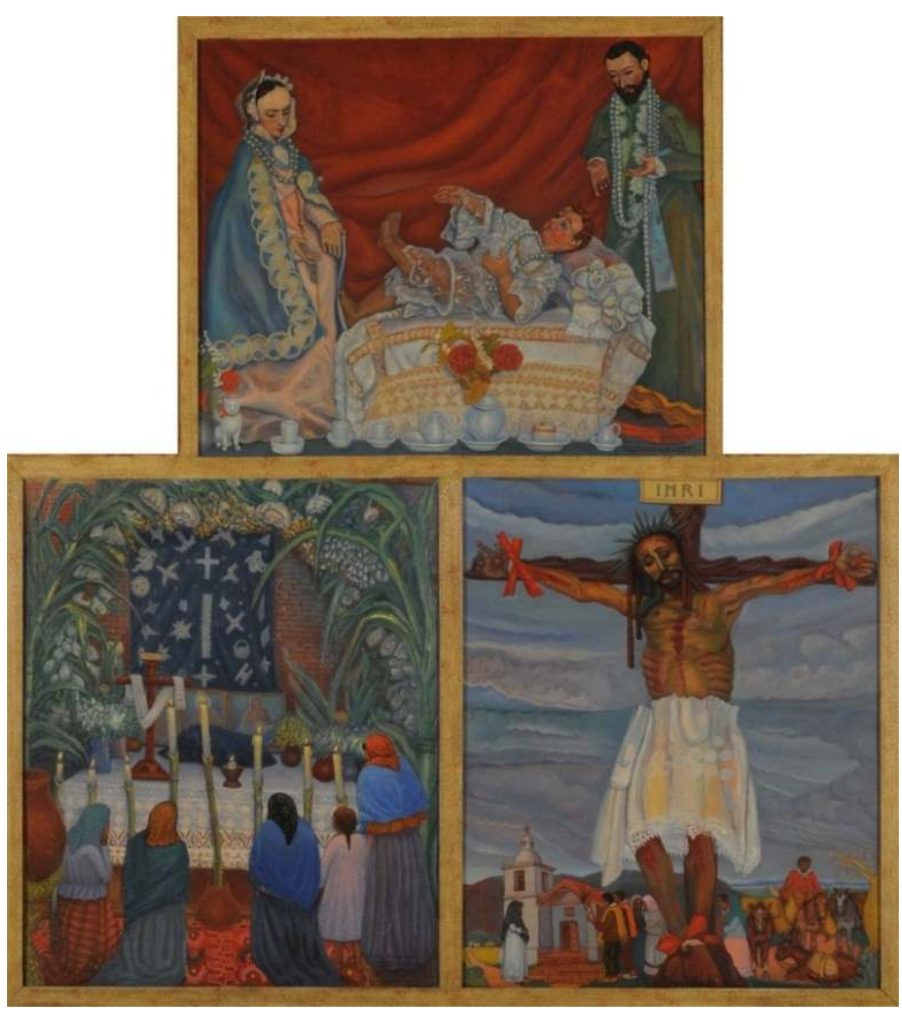

FiguRA 2: Alfredo Gramajo Gutiérrez, Retablo de Jesús, 1930-8, óleo sobre madera terciada, $65.5 \times 78.5$ cm - 66,3 x $78 \mathrm{~cm}-65.2 \times 79.1 \mathrm{~cm}$. Colección Museo Nacional de Bellas Artes, Buenos Aires. 


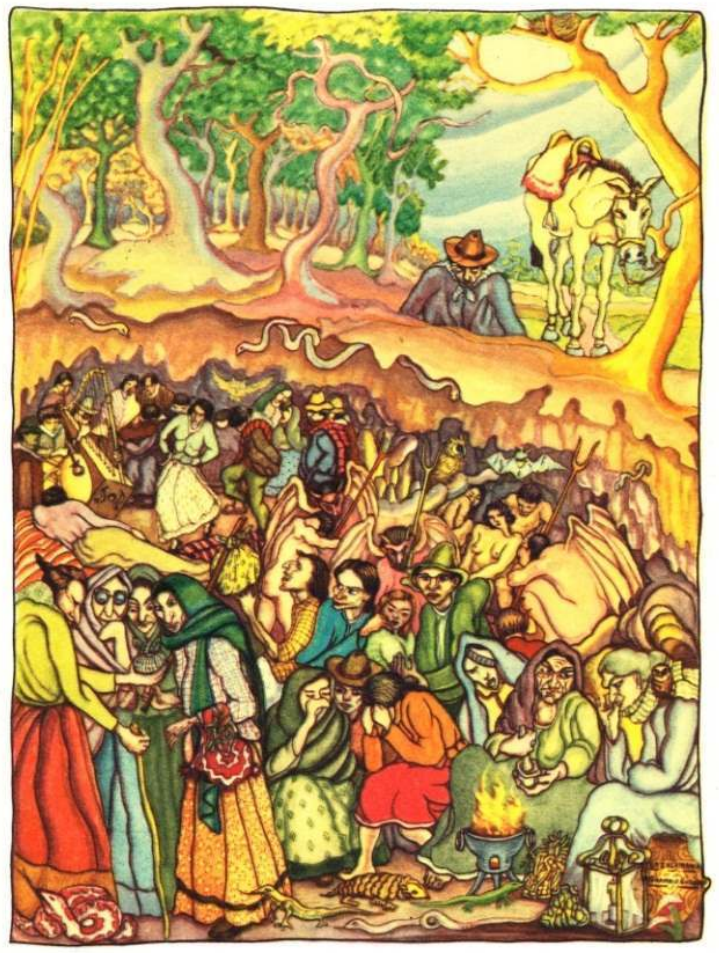

FIgURA 3: Alfredo Gramajo Gutiérrez, La Salamanca, ilustración incluida en la edición de 1946 de El País de la selva de Ricardo Rojas realizada por la editorial Guillermo Kraft de Buenos Aires.

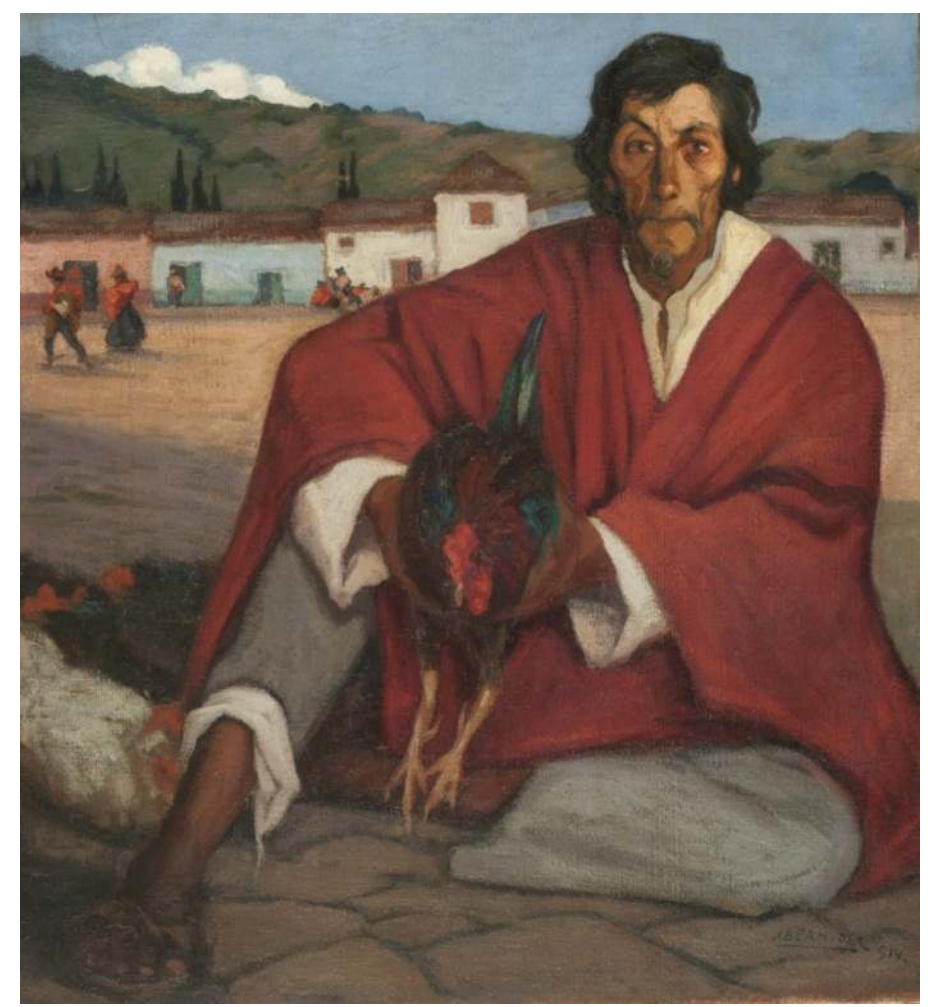

FIgURA 4: Jorge Bermúdez, Gallero viejo, 1914, óleo sobre tela, 111.5 x 105.5 cm. Colección Museo Nacional de Bellas Artes, Buenos Aires. 


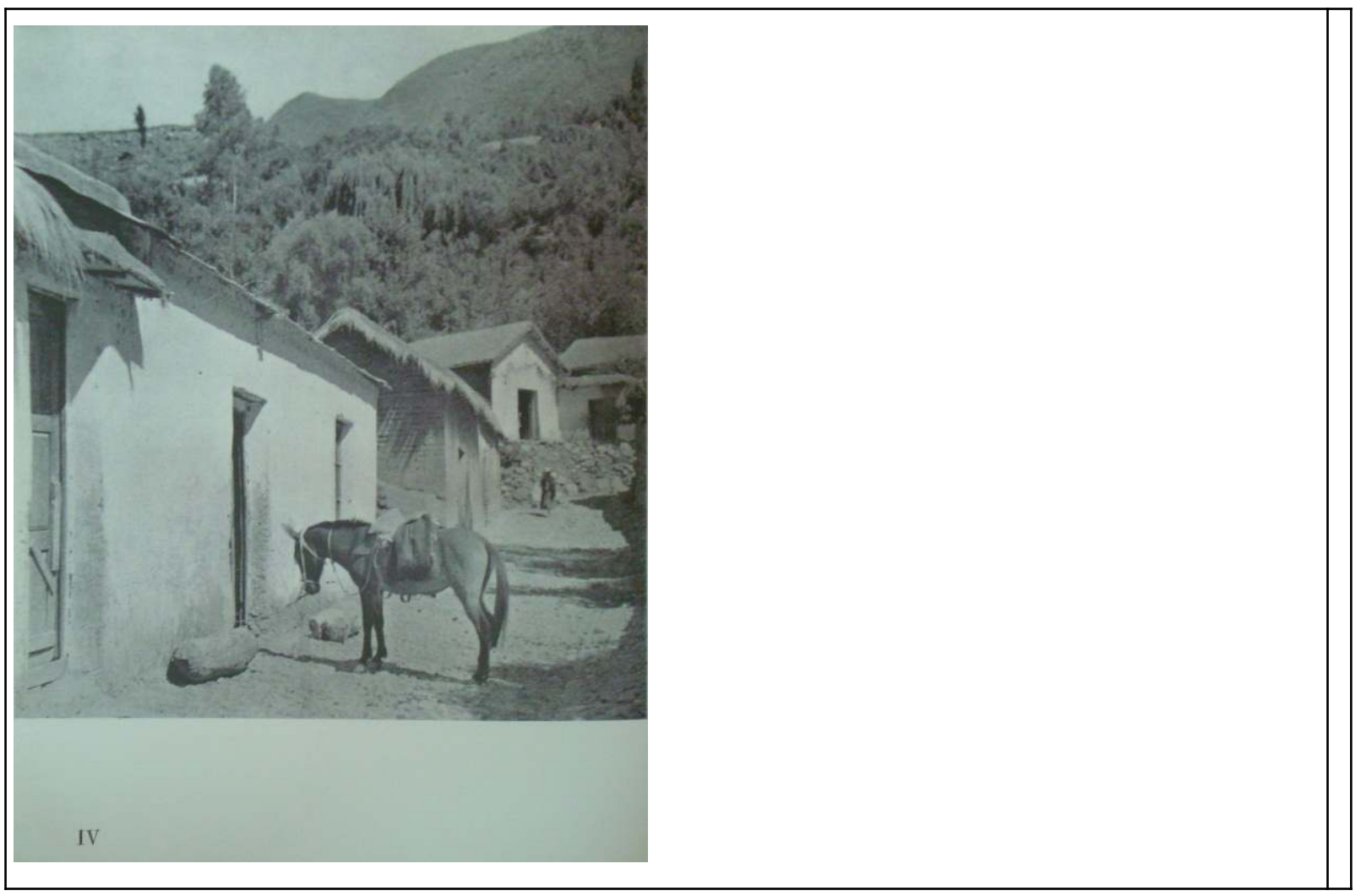

FiguRA 5: fotografía de Hans Mann reproducidas en Cuadernos de arte argentino. Ramificaciones de la Quebrada de Humahuaca y del camino de los Incas, Buenos Aires, AANBA, 1942.

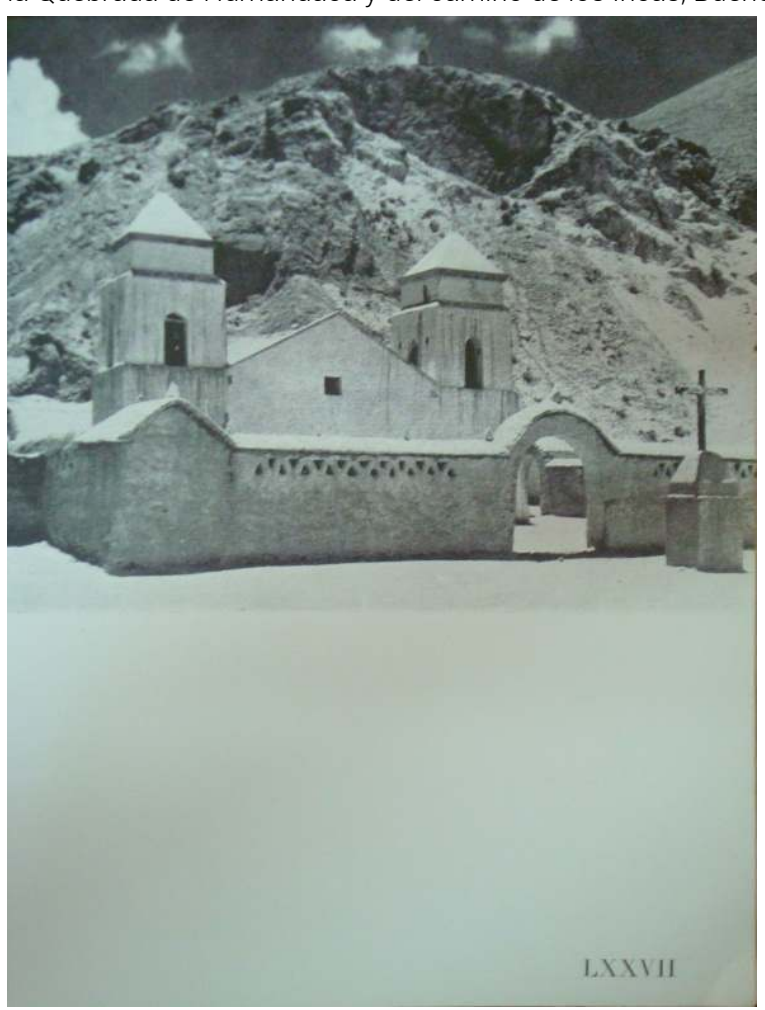

FiguRA 6: fotografía de Hans Mann reproducidas en Cuadernos de arte argentino. Ramificaciones de la Quebrada de Humahuaca y del camino de los Incas, Buenos Aires, AANBA, 1942 


\section{BIBLIOGRAFÍA}

AAVV, Cuzco-Buenos Aires. Ruta de intelectualidad americana (1900-1950), Lima, Universidad de San Martín de Porres, 2008

ADAMOVSKY, Ezequiel, “La cultura visual del criollismo: etnicidad, 'color' y nación en las representaciones visuales del criollo en Argentina, c. 1910-1955”, en Corpus, vol 6, ㄲ2, 2016. http://journals.openedition.org/corpusarchivos/1738

ALTAMIRANO, Carlos y SARLO, Beatriz, "La Argentina del Centenario: campo intelectual, vida literaria y temas ideológicos”, en Ensayos argentinos. De Sarmiento a la vanguardia, Buenos Aires, Ariel1997

AMIGO, Roberto, "La hora americana 1910-1950. El americanismo del indianismo al indigenismo", en La hora americana 1910-1950 (catálogo de exposición), Buenos Aires, MNBA, 2014

BERJMAN, Sonia y WECHSLER, Diana, "Martín Noel en las instituciones de Bellas Artes", en AAVV, El arquitecto Martín Noel. Su tiempo y su obra, Sevilla, Junta de Andalucía, 1995

BERNABÉU ALBERT, Salvador, “Los americanistas y el pasado de América: tendencias e instituciones en vísperas de la Guerra Civil”, Revista de Indias, vol. LXVII, nº239, 2007. http:// revistadeindias.revistas.csic.es/index.php/revistadeindias/article/view/599/665

BOVISIO, Marìa Alba, "Supuestos y conceptos acerca de la imagen precolombina del noroeste argentino en la obra de Samuel Lafone Quevedo, Adán Quiroga y Juan Ambrosetti”, Estudios Sociales del noa, no14, 2014. http://revistascientificas.filo.uba.ar/index.php/esnoa/article/ view/1114/1094

CHIÁPPORI, Atilio, "Jorge Bermúdez (recuerdos de una hora difícil y de un triunfo rotundo)", Nosotros, n²04, mayo de 1926

CHIÁPPORI, Atilio, La inmortalidad de una patria, Buenos Aires, Ministerio de Justicia e Instrucción Pública, 1942

DEL CAMPO, Cupertino, Jorge Bermúdez (catálogo de exposición), Buenos Aires, CNBA, 1926

DEVOTO, Fernando, Nacionalismo, fascismo y tradicionalismo en la Argentina moderna. Una historia, Buenos Aires, Siglo XXI, 2002

GÁLVEZ, Manuel , La vida múltiple, Buenos Aires, Nosotros, 1916

GARCÍA, Carla, "Los fósiles de la Academia". Martín Noel, Mario Buschiazzo y los itinerarios institucionales de la historiografía artística argentina". En caiana. Revista de Historia del Arte y Cultura Visual del Centro Argentino de Investigadores de Arte (CAIA). N 9, 2016. http:// caiana.caia.org.ar/template/caiana.php?pag=articles/article_1.php\&obj=245\&vol=9

GOEBEL, Michael, La Argentina partida. Nacionalismos y políticas de la historia, Buenos Aires, Prometeo, 2013

GUIDO, Ángel, Concepto moderno de la historia del arte, Santa Fe, Universidad Nacional del Litoral, 1935

GUIDO, Ángel, Redescubrimiento de América en el arte, Rosario, Universidad del Litoral, 1945 
GUTMAN, Margarita, "Martín Noel y el neocolonial en Argentina: inventando una tradición”, en AAVV, El arquitecto Martín Noel. Su tiempo y su obra, Sevilla, Junta de Andalucía, 1995

LUDMER, Josefina, El género gauchesco. Un tratado sobre la patria, Buenos Aires, Eterna Cadencia, 1988 [2012]

LUGONES, Leopoldo, El payador, Buenos Aires, Biblioteca Nacional, 1916 [2009]

LUGONES, Leopoldo, “El pintor nacional”, La Nación, Buenos Aires, 27 de mayo de 1920

LVOVICH, Daniel, El nacionalismo de derecha. Desde sus orígenes a Tacuara, Buenos Aires, Capital Intelectual, 2006

MALOSETTI COSTA, Laura, Los primeros modernos. Arte y sociedad en Buenos Aires a fines del siglo XIX, Buenos Aires, Fondo de Cultura Económica, 2001

MALOSETTI COSTA, Laura, Collivadino, Buenos Aires, El Ateneo, 2006

MALOSETTI COSTA, Laura y PENHOS, Marta, “Imágenes para el desierto argentino. Apuntes para una iconografía de la pampa", en Ciudad/campo en las Artes en Argentina y Latinoamérica. $3^{\circ}$ Jonradas de Teoría e Historia de las Artes, Buenos Aires, CAIA, 1991

MANTOVANI, Larisa, "Literatoides, superhombres, estudiantes y trabajadores: los conflictos estudiantiles en la Academia Nacional de Bellas Artes al inicio de la dirección de Pío Collivadino", ponencia presentada en III Encuentro de Jóvenes Investigadores en Arte, CAIA. Buenos Aires, 12 al 14 de octubre, 2016

MUÑOZ, Miguel Ángel, “Un campo para el arte argentino”, en WECHSLER, Diana (coord.), Desde la otra vereda. Momentos en el debate por un arte moderno en la Argentina (1880-1960), Buenos Aires, Ediciones del Jilguero, 1998

MUÑOZ, Miguel Ángel, “Obertura 1910: la Exposición Internacional del Centenario”, en PENHOS, Penhos y WECHSLER, Diana (coord.), Tras los pasos de la norma. Salones Nacionales de Bellas Artes (1911-1989), Buenos Aires, Ediciones del Jilguero, 1999

NASTRI, Javier, “Los primeros americanistas (1876-1900) la construcción arqueológica del pasado de los Valles Calchaquíes (Noroeste argentino)”, en HABER, Alejandro (comp.), Hacia una arqueología de las arqueologías sudamericanas, Bogotá, CESO-UNIANDES, 2004

NOEL, Martín, Teoría histórica de la arquitectura virreinal, Buenos Aires, Peuser, 1932

NOEL, Martín, Estudios y documentos para la historia del arte colonial, Buenos Aires, FFyL-UBA, 1934

NOEL, Martín, Palabras en acción, Buenos Aires, Peuser, 1945

PEGORARO, Andrea, Las colecciones del Museo Etnográfico de la Universidad de Buenos Aires: un episodio en la historia del americanismo en la Argentina (1890-1927), Tesis de doctorado, FFyLUBA, mimeo, 2009

PENA, Carmen, “Centro y periferia en la modernización de la pintura española, 1880-1918”, en PRIEGO, Carlos (coord.), Las artes españolas en la crisis del 98, Oviedo, Universidad de Oviedo, 1996

PENHOS, Marta, "Nativos en el salón. Artes plásticas e identidad en la primera mitad del siglo XX", en PENHOS, Penhos y WECHSLER, Diana (coord.), Tras los pasos de la norma. Salones Nacionales de Bellas Artes (1911-1989), Buenos Aires, Ediciones del Jilguero, 1999

PRIETO, Adolfo, El discruso criollista en la formación de la argentina moderna, Buenos Aires, Siglo XXI, 1988 [2006] 
RIPAMONTE, Carlos, Janus. Consideraciones y reflexiones artísticas, Buenos Aires, M. Gleizer, 1926

ROJAS, Ricardo, Historia de la literatura argentina. Los gauchescos, Buenos Aires, Roldán, 1917

ROJAS, Ricardo, “La obra de Jorge Bermúdez”, en Jorge Bermúdez (catálogo de exposición), Buenos Aires, Galería Witcomb, 1923

ROJAS, Ricardo, Eurindia. Ensayo de estética sobre las culturas americanas, Buenos Aires, CEAL, 1924 [1980]

ROJAS, Ricardo, Silabario de la decoración americana, Buenos Aires, Losada 1930 [1953]

ROSSI, Cristina, "Cambios de rumbo. Nuevas orientaciones en las rutas artísticas entre 1940 y 1960", en BALDASARRE, María Isabel y DOLINKO, Silvia (eds.), Travesías de la imagen. Historias de las artes visuales en la Argentina (volumen II), Bueos Aires, Eduntref, 2012

\section{NOTAS}

1. Por "noroeste argentino" me refiero a la región que abarca a los territorios de las actuales provincias de Santiago del Estero, La Rioja, Catamarca, Tucumán, Salta y Jujuy. Esta amplia porción del país posee una amplia variedad de geografías y biomas, que incluyen al monte, la yunga, los valles y quebradas, la cordillera andina y hasta el altiplano puneño. No obstante, aunque su definición ha variado en el tiempo, la unidad imaginada del noroeste ha girado fundamentalmente alrededor de un pasado común a toda esta amplia zona: la presencia de un conjunto de sociedades prehispánicas con cosmovisiones y culturas materiales emparentadas con las de los grupos que habitaron los Andes Centrales y la temprana ocupación española, que integró a la región al Virreinato del Alto Perú.

2. Aquí me hago eco del acertado señalamiento de Amigo, que marcó la diferencia entre el sentido del término nativismo en Argentina y aquel empleado en Estados Unidos, donde el concepto fue cargado de xenofobia. Ver: (AMIGO, 2014: 51).

3. En este punto difiero con la posición de los autores de Cuzco-Buenos Aires, que afirman que el criollismo gauchesco hegemonizó la mirada sobre lo nativo, transformándose en emblema de la nacionalidad (AAVV, 2008: 13).

4. El grupo Nexus estuvo integrado por Pío Collivadino, Carlos Ripamonte, Fernando Fader, Justo Lynch, Alberto M. Rossi, Arturo Dresco, Cesáreo Bernaldo de Quirós y Rogelio Yrurtia; de corta vida, produjo tres exposiciones entre 1907 y 1908.

5. En 1908 Collivadino reemplazó al pintor Ernesto de la Cárcova como director de la Academia de Bellas Artes fundada tres años antes; poco tiempo después Ripamonte se le sumó como vicedirector de la institución. El pintor Eduardo Schiaffino, que dirigía el Museo Nacional de Bellas Artes (creado por decreto en 1895) y la Comisión Nacional de Bellas Artes (creada en 1897), también fue desplazado de sus cargos.

6. Laura Malosetti Costa señaló que los miembros de Nexus y sus allegados establecieron una crítica velada (rastreable en cartas y escritos autobiográficos) a sus antecesores, centrada en la percepción de un agotamiento de sus gestiones, vitales a la hora de fundar las primeras instituciones pero restrictivas e improductivas en el nuevo contexto (MALOSETTI COSTA, 2006: 73). En ocasiones, la sucesión de cargos generó conflictos abiertos: tal fue el caso de la designación de Collivadino como director de la academia que, como ha señalado Larisa Mantovani, desató una huelga estudiantil (MANTOVANI, 2016).

7. Aunque esquemática, esta caracterización se ajusta a la percepción que de ellos tuvieron los artistas e intelectuales de la generación siguiente: en este sentido, la reconstrucción de los 
debates de la época que realizó Muñoz señaló cómo Schiaffino era señalado de manera peyorativa como un "afrancesado" por el crítico del diario La Razón, que en contraposición erige a Ripamonte como uno de los mayores valores de la plástica argentina (MUÑOZ, 1998: 55). No obstante, no debe dejar de señalarse que el interés por el problema del "arte nacional" en los artistas de la Generación del '80 tiene puntos de contacto con las posiciones de algunos de sus sucesores; al respecto, véase el análisis de Malosetti Costa sobre los debates entre Schiaffino y Rafael Obligado en torno a la cuestión del paisaje (MALOSETTI COSTA, 2001: 337 a 347).

8. El regionalismo español fue un movimiento pictórico vasto y relativamente heterogéneo, que tuvo lugar entre las últimas décadas del siglo XIX y las primeras del siglo XX. Vinculado con el contexto de la crisis suscitada por la disolución final del Imperio Español en 1898, los pintores optaron por redirigir su mirada hacia la periferia rural del país en búsqueda del paisaje y las comunidades campesinas, elementos "esenciales" de la identidad española (PENA, 1996).

9. Los intelectuales del Centenario no fueron los únicos que reflexionaron sobre la problemática de la inmigración: la "generación del " 80 " ya había señalado el efecto "disolvente" que las tradiciones y costumbres de nuevos habitantes tendrían sobre la identidad nacional, posturas reflejadas en el pensamiento de Miguel Cané y de José María Ramos Mejía, entre otros (TERÁN., 2000). Por otra parte, el espiritualismo ya se había manifestado, por ejemplo, en célebre Ariel del uruguayo José Enrique Rodó, publicado al iniciar del siglo XX. Según Daniel Lvovich, una parte considerable de los tópicos del nacionalismo cultural ya se encontraban planteados en el pensamiento de la década de 1890, por lo que la llegada de los intelectuales del Centenario no fue percibida en términos disruptivos (LVOVICH, 2006: 18).

10. Quizás el contraste mayor se dio entre Rojas y Lugones: mientras que el primero se enroló en las filas del radicalismo yrigoyenista hacia finales de la década de 1920, el otro se decantó por formas de gobierno autoritarias, posición que dejó plasmada en su criticado discurso de 1924 por el centenario de la batalla de Ayacucho.

11. Devoto y Goebel coinciden en que los intelectuales del Centenario, por sus continuidades con el pensamiento liberal, en ningún momento proyectaron la impugnación o alteración del panteón de próceres mitrista. Esta operación no tendría lugar hasta el surgimiento del revisionismo como deriva de la tradición nacionalista.

12. La argumentación de Lugones alrededor de la voz del gaucho es quizás la más compleja: al rescatar la sensibilidad espiritual del gaucho en su faceta de cantor, organiza una cadena de correspondencias en la que se articulan rapsoda, payador, Hernández y él mismo. Ver: (LUGONES, 1916) y (ROJAS, 1917).

13. La operación de los dos intelectuales se montó sobre una cadena de representaciones construida en el tiempo. Josefina Ludmer ha demostrado que el establecimiento del género gauchesco supuso una apropiación de la voz de los sujetos subalternos por parte la cultura letrada, procedimiento lingüístico que se corresponde con el uso de los cuerpos de los gauchos que hizo el ejército a partir del mecanismo de la leva (LUDMER, 1988). Por otro lado, Adolfo Prieto reconstruyó la circulación de los folletines criollistas y señaló su rol en la nacionalización de los contingentes de inmigrantes, la evocación nostálgica por parte de las poblaciones desplazadas del campo a la ciudad y la afirmación de la legitimidad de las elites tradicionales (PRIETO, 1988).

14. Ameghino fue el primero en proponer esta hipótesis: ya en el Congreso Internacional de Americanistas celebrado en Bruselas en 1879 sostuvo que los hallazgos arqueológicos de Loma Rica de Shiquimil, provincia de Catamarca, eran obra de un pueblo pre incaico cuyo dialecto venía del aymara y descendía de la civilización de Tihuanaco. Por su parte, a partir de 1888 Lafone Quevedo elaboró la hipótesis de que la "civilización calchaquí" habría sido invadida por tribus chaqueñas (lo cual se explicaba por la similitud de sus prácticas funerarias), resultando de su mezcla la cultura diaguita que conocieron los españoles. Entre los argumentos que sumó Ambrosetti posteriormente, se suma su observación de que los menhires de Tafí del Valle habían 
sobrevivido a la destrucción a manos de los jesuitas ya que en ese momento no eran venerados por los indios, indicio de que formaban parte de una cultura del pasado diferente a la de esos pueblos. Quiroga, por su parte, aportó observaciones para distinguir a la cultura de La Ciénaga del amplio conjunto de lo calchaquí. Ver: (NASTRI, 2004).

15. La historia del americanismo europeo comenzó en 1857 con la fundación de la Société Américaine de France, que comenzó a organizar congresos internacionales a partir de 1875.

16. No obstante, las campañas de recolección etnográfica quedaron en un segundo plano, puesto que ninguno de los dos arqueólogos manifestó interés por los indígenas que les eran contemporáneos; en esta actitud hay una distancia con los artistas que, como veremos en el apartado siguiente, emprendieron viajes al noroeste para representar sus paisajes y pobladores. Aun así, también debe señalarse que la única misión etnográfica organizada por el Museo Etnográfico durante las primeras gestiones tuvo lugar en los ingenios azucareros de Jujuy durante 1909: dado que esos establecimientos utilizaban a los indios como mano de obra estacional eran considerados espacios privilegiados para el trabajo de los etnólogos. Ver: (PEGORARO, 2009).

17. Información biográfica presente en la carpeta de José Antonio Terry. Archivo del Palais de Glace.

18. El panel superior se titula Retablo de Jesús: el Niño Dios, la Virgen y San José, nacimiento antiguo y está fechado en 1938; el panel inferior izquierdo se llama Viernes Santo, el Calvario del Señor (Semana Santa - abril de 1930) y fue realizado en Chumbicha en 1930; el último panel lleva como título Crucificción y muerte. El señor de los Milagros y su leyenda - Cristo antiguo que se venera en la Iglesita de la Tercena - Catamarca - desde el año 1793 y fue realizado en 1934. Gramajo Gutiérrez recibió el segundo premio de pintura en el Salón Nacional del año 1939 por el conjunto.

19. Si bien Gálvez no menciona a los detractores de Bermúdez, posiblemente uno de ellos fuera Atilio Chiappori: en la edición homenaje que Nosotros editó tras la muerte del pintor, Chiappori recordó y lamentó el efecto negativo que había tenido en el artista la crítica que él había publicado en su revista Pallas, donde señalaba la dependencia respecto del estilo de Zuloaga (CHIAPPORI, 1926).

20. "Al apartarse cada vez más de la influencia de sus maestros, al ponerse en contacto con nuestra naturaleza y nuestra vida argentinas, irán surgiendo aquellas cualidades, las que no tardarán en mostrarse, para honor del arte nacional, en magníficas floraciones de belleza." (GÁLVEZ, 1916: 98)

21. Esta información es proporcionada por Cupertino del Campo en el ensayo publicado en el catálogo de la exposición póstuma de Bermúdez, donde afirma que el argentino recibió una carta en la que el maestro español formuló el consejo. (DEL CAMPO, 1926)

22. Un artículo escrito tras la muerte de Bermúdez por Laureano Brizuela, discípulo catamarqueño del pintor, revela algunos posibles indicios de su interés por esa provincia. Al parecer Bermúdez ya había visitado Catamarca antes de recibir la beca de formación en Europa; su viaje había sido motivado por su amistad con Enrique Ocampo (gobernador de la provincia) y Emilio Molina (presidente del Consejo de Educación de la misma repartición). "Jorge Bermúdez", recorte de diario sin fecha, archivo Graciela Pernasetti, Catamarca.

23. En 1924 Bermúdez se radicó en Granada, España, tras adquirir un cargo como cónsul; dos años después falleció.

24. No confundir con la academia nacionalizada en 1905.

25. Es importante señalar que Noel no era un agente externo a los debates americanistas locales. En el Museo Etnográfico de la Universidad de Buenos Aires se conserva una carpeta que contiene una serie de documentos relativos a la Sociedad Americanista de Buenos Aires, una institución que tuvo sede en esa institución y que tuvo como miembros a eminentes arqueólogos, folkloristas, historiadores e intelectuales, entre los que se contaba a Noel; si bien los registros de sus primeras asambleas datan de 1927, desconozco cuál fue el período temporal y las actividades 
de la sociedad. Ver: carpeta "Sociedad Americanista de Buenos Aires", fondo Salvador Debenedetti, Archivo del Museo Etnográfico de Buenos Aires.

26. Los principales libros de Noel están basados en las conferencias y cursos que dictó a lo largo de su vida, fundamentalmente los que dictó en la Universidad de Sevilla en 1930 y en el Instituto de Investigaciones Históricas de la Facultad de Filosofía y Letras de la UBA en 1932; en ellos sostuvo la hipótesis general de que a partir del siglo XVII se produjo la eclosión de una arquitectura netamente hispanoamericana, en la que los ritmos mecanicistas y abstractos de las artes peruanas se entretejieron con la geometría mudéjar y dieron como resultado un nuevo lenguaje ornamental (NOEL, 1932 y 1934). Guido planteó un sistema de pensamiento mucho más abarcador: partiendo de la doctrina euríndica de Rojas y de la metodología del visibilismo (especialmente de Heinrich Wölfflin y Wilhelm Worringer) sostuvo que en América se había producido una primera emancipación estética a partir de la reacción criolla frente al arte español y que debía ser retomada en el distanciamiento contemporáneo respecto del cosmopolitismo del siglo XIX (GUIDO, 1935 y 1945). Estas ideas también guiaron a los dos arquitectos en la elaboración del estilo neocolonial, que tuvo entre sus ejemplos más notables a la casa que Guido construyó para Rojas o el pabellón argentino que Noel diseñó para la Exposición Iberoamericana de Sevilla, ambos de 1929.

27. La lista completa estaba integrada por Pío Collivadino (director de la Academia), Cupertino del Campo (autoridad del MNBA), Alberto de Barry, Ernesto de la Cárcova, Jorge Bermúdez, Rogelio Yrurtia, Alberto Lagos, Alfredo González Garaño, Mario Canale y Carlos López Buchardo.

28. Si bien el reglamento estipulaba la repetición anual de este premio, no he encontrado referencias que permitan constatar si esto efectivamente sucedió.

29. De los treinta y tres volúmenes de los Documentos de arte argentino, doce se dedicaron a temas vinculados al noroeste. La serie desató una resonante polémica historiográfica: desde 1949 las páginas de los Anales del Instituto de Arte Americano e Investigaciones Estéticas incluyeron un conjunto de artículos críticos de Mario Buschiazzo y sus discípulos Hector Schenone y Adolfo Ribera, que sistemáticamente señalaron las inexactitudes históricas y los defectos metodológicos en la lectura de las fuentes en las que incurrieron los documentos de la ANBA, en un esfuerzo por dotar a la historia del arte de una mayor solidez científica. Ver: (GARCíA, 2016).

30. De acuerdo a las memorias publicadas por la Comisión Nacional de Cultura, algunos de los becarios enviados al noroeste fueron: el escultor Máximo Maldonado y el pintor Ernesto Scotti (premiados en 1940), el pintor Antonio Berni (1941), el pintor Carlos Torraldona y el escultor Nicasio Fernández Mar (1942), los pintores Guido Amicarelli y Juan Carlos Faggioli y el escultor José Alonso (1943), el pintor Domingo Mazzone (1945) y el escultor Antonio Nevot (1946). Agradezco a Cristina Rossi por facilitarme estas fuentes.

\section{RESÚMENES}

El presente artículo se propone investigar la construcción de los imaginarios visuales y estéticos sobre el noroeste argentino desarrollados durante la primera mitad del siglo XX. Durante este período las preguntas por las condiciones del "arte nacional" derivaron en un interés por la representación del paisaje y los tipos humanos de las provincias del país; el noroeste se destacó como la región de mayor concentración de aquellos elementos significantes. A lo largo del texto reconstruiré los vínculos entre estos imaginarios y el desarrollo del pensamiento nacionalista y la arqueología, identificaré algunos de los modelos visuales más 
relevantes y rastrearé la incidencia de estas ideas estéticas en la historiografía y las instituciones artísticas oficiales.

Le présent article vise à étudier la construction d'imaginaires visuels et esthétiques du nordouest de l'Argentine développée au cours de la première moitié du XXème siècle. Pendant cette période les questions sur les conditions de "l'art national" dérivaient d'un intérêt pour la représentation du paysage et les types humains des provinces du pays; le nord-ouest a été mis en évidence comme la région de plus grande concentration de ces éléments signifiants. Tout au long du texte, je reconstituerai les liens entre ces imaginaires et le développement de la pensée et de l'archéologie nationalistes, identifierai certains des modèles visuels les plus remarquables et explorerai l'incidence de ces idées esthétiques dans l'historiographie et les institutions artistiques officielles.

\section{ÍNDICE}

Mots-clés: noroeste - nativismo - americanismo - regionalismo - modernidad - arte argentino Palabras claves: noroeste - nativismo - americanismo - regionalismo - modernidad - arte argentino

\section{AUTOR}

\section{PABLO FASCE}

CONICET - IDAES/UNSAM - UBA (Doctor en historia por el Instituto de Altos Estudios Sociales de la Universidad de San Martín, Argentina, Becario posdoctoral CONICET. Su investigación gira en torno al proceso de institucionalización de las artes en el noroeste argentino y las redes de intercambio de intelectuales y artistas a lo largo de la región andina durante la primera mitad del siglo XX.) 